\title{
2010s-04
}

\section{Private Valuation of a Public Good in Three Auction Mechanisms}

\author{
Arnaud Z. Dragicevic, David Ettinger
}

\begin{tabular}{c}
\hline Série Scientifique \\
Scientific Series
\end{tabular}

\author{
Montréal \\ Janvier 2010
}

(C) 2010 Arnaud Z. Dragicevic, David Ettinger. Tous droits réservés. All rights reserved. Reproduction partielle permise avec citation du document source, incluant la notice (C).

Short sections may be quoted without explicit permission, if full credit, including (C) notice, is given to the source.
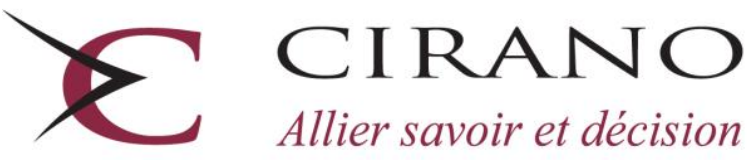

Allier savoir et décision

Centre interuniversitaire de recherche en analyse des organisations 


\section{CIRANO}

Le CIRANO est un organisme sans but lucratif constitué en vertu de la Loi des compagnies du Québec. Le financement de son infrastructure et de ses activités de recherche provient des cotisations de ses organisations-membres, d'une subvention d'infrastructure du Ministère du Développement économique et régional et de la Recherche, de même que des subventions et mandats obtenus par ses équipes de recherche.

CIRANO is a private non-profit organization incorporated under the Québec Companies Act. Its infrastructure and research activities are funded through fees paid by member organizations, an infrastructure grant from the Ministère du Développement économique et régional et de la Recherche, and grants and research mandates obtained by its research teams.

\section{Les partenaires du CIRANO}

Partenaire majeur

Ministère du Développement économique, de l'Innovation et de l'Exportation

\section{Partenaires corporatifs}

Banque de développement du Canada

Banque du Canada

Banque Laurentienne du Canada

Banque Nationale du Canada

Banque Royale du Canada

Banque Scotia

Bell Canada

BMO Groupe financier

Caisse de dépôt et placement du Québec

Fédération des caisses Desjardins du Québec

Financière Sun Life, Québec

Gaz Métro

Hydro-Québec

Industrie Canada

Investissements PSP

Ministère des Finances du Québec

Power Corporation du Canada

Raymond Chabot Grant Thornton

Rio Tinto

State Street Global Advisors

Transat A.T.

Ville de Montréal

\section{Partenaires universitaires}

École Polytechnique de Montréal

HEC Montréal

McGill University

Université Concordia

Université de Montréal

Université de Sherbrooke

Université du Québec

Université du Québec à Montréal

Université Laval

Le CIRANO collabore avec de nombreux centres et chaires de recherche universitaires dont on peut consulter la liste sur son site web.

Les cahiers de la série scientifique (CS) visent à rendre accessibles des résultats de recherche effectuée au CIRANO afin de susciter échanges et commentaires. Ces cahiers sont écrits dans le style des publications scientifiques. Les idées et les opinions émises sont sous l'unique responsabilité des auteurs et ne représentent pas nécessairement les positions du CIRANO ou de ses partenaires.

This paper presents research carried out at CIRANO and aims at encouraging discussion and comment. The observations and viewpoints expressed are the sole responsibility of the authors. They do not necessarily represent positions of CIRANO or its partners. 


\title{
Private Valuation of a Public Good in Three Auction Mechanisms
}

\author{
Arnaud Z. Dragicevic ${ }^{*}$, David Ettinger ${ }^{\dagger}$
}

\begin{abstract}
Résumé / Abstract
Nous évaluons l'impact de trois mécanismes d'enchère - le mécanisme Becker-DeGrootMarschak (BDM), l'enchère au deuxième prix, et l'enchère aléatoire au nième prix - dans l'évaluation des consentement-à-payer et consentement-à-recevoir privés d'un bien public pur. Nos résultats montrent que l'effet de dotation peut être éliminé en répétant le mécanisme BDM. Néanmoins, à l'échelle logarithmique, l'enchère aléatoire au nième prix donne la vitesse de convergence vers l'égalité des indices de bien-être la plus élevée. Plus généralement, nous observons que les sujets d'étude évaluent les biens publics en se référant à l'avantage privé et subjectif qui résulte du financement du bien public.
\end{abstract}

Mots clés : évaluation contingente, Ecart CAP-CAR, enchères, provision privée des biens publics.

We evaluate the impact of three auction mechanisms - the Becker-DeGroot-Marschak (BDM) mechanism, the second-price auction (SPA), and the random nth-price auction (NPA) - in the measurement of private willingness-to-pay and willingness-to-accept for a pure public good. Our results show that the endowment effect is lower with the BDM mechanism. In this market mechanism, the effect disappears after a few repetitions. Yet, on a logarithmic scale, the random nth-price auction yields the highest speed of convergence toward equality of welfare indices. We also observe that subjects value public goods in reference to their private subjective benefit derived from their public good funding.

Keywords: WTP-WTA disparity, auction mechanisms, public goods, private provisions.

Codes JEL : C91, D44, Q53

\footnotetext{
"CIRANO and École Polytechnique ParisTech. CIRANO, 2020 rue University, Montréal (QC) H3A 2A5 Canada, arnaud.dragicevic@cirano.qc.ca.

${ }^{\dagger}$ Université de Cergy-Pontoise and THEMA, 95000 Cergy-Pontoise Cedex, France.
} 
"I have never known much good done by those who affected to trade for the public good." Adam Smith

\section{Introduction}

The experimental private provision of public goods based on contingent valuation is used to value public goods such as health, safety or the environment. Estimating preferences for goods is laborious, because individuals reveal behavioral biases during their valuation process. Our motivation is to study how subjects apprehend public goods in auction mechanisms, for public goods are not traded on markets. In case subjects do want to trade public goods on markets, which value do they assign to the public good, given the negligible private utility derived from it? Which auction mechanism is the best and fastest at reducing the gap between willingness-to-pay (WTP), which is the price at which an individual is ready to buy a commodity, and willingnessto-accept (WTA), which is the price at which an individual is ready to sell the same commodity?

Neoclassical theory postulates that with null income effect and close substitutes, WTP and WTA should be equal (Randall and Stoll 1980, Hanemann 1991), which is also in accordance with Coase (1960). If a good is available at market price on an active market, WTP and WTA should be similar. Yet, experimental research has found disparities. The endowment effect, or loss aversion, as a behavioral feature is often invoked to explain the disparity. It occurs when people offer to sell a commonly available good in their possession at a substantially higher rate than they would pay for the identical good not in their possession. The other effect, promoted to explain the disparity, is imperfect substitutability. Two remedies help remove the initial disparity. The first corresponds to market settings. Market institutions serve as social tools that induce and reinforce individual rationality (Smith 1991). Gode and Sunder (1993) assert that an auction market exerts a powerful constraining force on individual behavior. Cherry et al. (2003) suggest that a dynamic market environment with repeated exposure to discipline is necessary to achieve rationality. When they act rationally, individuals refine their statements of value. List (2003a) provides evidence consistent with the notion that experience in bidding with an incentivecompatible auction can remove the WTA/WTP gap. The second remedy corresponds to market repetition. The motive for repeating auctions that are incentive-compatible is that individuals require experience to understand that sincere bidding is the dominant strategy (Coppinger et al. 
1980) and to realize their true valuation of unfamiliar products (Shogren et al. 2000). Plott (1996) advances a discovered preference hypothesis argument, positing that responses reflect a type of internal search process in which subjects use practice rounds to discover their preferences. The experience they gain is reflected in their bidding behavior. Hence, the imperfect substitutability effect disappears when the value of the unfamiliar good is perfectly revealed.

Kahneman et al. (1990) report experimental evidence of the endowment effect. They perform a hypothetical telephone inquiry, trading environmental improvements and preparedness for disasters. To elicit value estimates, they use the Becker-DeGroot-Marschak (BDM) mechanism and find that randomly assigned owners of an item require more money to separate from their possession than random buyers are willing to pay to acquire it. According to their results, preferences are dependent on endowments, even in market settings. Shogren et al. (1994) assert that the experiment conducted by Kahneman et al. creates artificial scarcity. They find no evidence of the endowment effect on trading candy bars, for the values converge over time. But, in the contaminated food experiment - a good with imperfect substitutes that can be considered as nonmarketed - they show that the discrepancy remains significant after iteration. While the authors support the idea of a low substitution elasticity of the nonmarket good, they do not advocate the institution capable of valuing nonmarket goods. Later on, Shogren et al. (2001) test the BDM mechanism, the Vickrey's second price auction (SPA) and the random $n$ th-price auction (NPA) to exchange candy bars and mugs, and suggest that the type of auction mechanism accounts for contrasting observations in experiments. They show that the early disparity is not to be called into question. However, the gap ebbs away under SPA and NPA while it lasts under BDM. Therefore, Plott and Zeiler's (2005) claim that results differ from unsound experimental procedures is incomplete. Only List (2003b) gives credit to the use of the random $n$ th-price auction in valuing nonmarket private goods, but he does not state whether his results carry over to public goods.

Horowitz (2006a) states that the BDM framework could be used to assess public WTP for public projects, with the distribution of costs equal to the project costs; and that other valuation mechanisms should be used if the behavioral evidence shows that outcomes are equivalent whatever the mechanism. Lusk and Rousu (2006) suggest that NPA is preferable to BDM if the researcher is looking for true valuation above all. Lusk et al. (2007) conclude that both "provide 
relatively strong incentives for truthful bidding for all individuals regardless of the magnitude of their true WTP."

We aim at studying private valuation of a public good without direct substitutes, so we put the carbon offset, which can be attained via tree planting, into auctioning. Public goods have two defining characteristics: non-excludability and non-rivalry. Offsetting carbon emission helps prevent the effects of climate change; it is considered a public good because, once provided, everyone can enjoy the benefits without adversely affecting anyone else's ability to do the same ${ }^{1}$. Rather than compulsory carbon trade, we institute voluntary trade to approach truthful valuation on both the bidder's (buyer's) and the offerer's (seller's) sides. On account of the common bias of nescience ${ }^{2}$ in valuing unfamiliar or public goods, we remind the subjects that they are part of the socio-economic setting. This makes them indirectly and partly accountable for the current level of greenhouse gases, as they solicit industries to produce goods they are willing to consume at an environmental cost. In our case, it is the paper and energy used by students to achieve their education $^{3}$. Our experiments differ from the early auction mechanisms for discrete public goods based on the Lindahl equilibrium by Smith (1979), which require that subjects unanimously agree to the public good quantity and cost shares according to their marginal benefits, otherwise no public good is provided.

Our results show that the initial disparity between WTP and WTA can be removed by means of repetitive auction mechanisms. Nevertheless, we obtain different results from Shogren et al. (2001). The only mechanism able to remove the gap between bids and offers for a public good is BDM. SPA and NPA do not succeed in eliminating the disparity. Still, when we conduct an exponential regression, we find that NPA yields the highest speed of convergence toward equality of welfare indices, suggesting that it contains strong incentives for rational behavior. As a final point, we observe that subjects are strongly motivated by the subjective private benefit

\footnotetext{
${ }^{1}$ We ensured the public good characteristic by providing an email feedback on the aggregate offset achievement to every subject after a few weeks.

${ }^{2}$ It reflects the absence of knowledge or the consideration that things are unknowable.

3 The money released from trading (buying and non-selling) was sent to a non-governmental organization that launched a plantation of 1,404 Mangrove trees in Sumatra, Indonesia.
} 
from funding the public good (either due to warm-glow ${ }^{4}$ or due to a concern for being formally identified as a contributor of the public good).

The remainder of this paper proceeds as follows. Section 2 describes the experimental design. Section 3 presents results and an analysis of data with standard and novel statistical tools. Section 4 discusses the differences between auction mechanisms and their relations with existing work, and presents a new line of reasoning. We clarify the difference between public and private motivations for the public good funding in Section 5 and conclude with Section 6.

\section{The experimental framework}

We want to evaluate the impact of three incentive-compatible auction mechanisms in the measurement of WTP and WTA for a public good without close substitute. Our experiments were conducted during three sessions at the École Polytechnique. Different subjects took part in each of the three sessions (three auction mechanism). A total of 102 participants were divided in three groups of subjects, which in turn were arbitrarily divided into two subgroups of buyers and sellers. Each subject received an identification number she filled in on each bid or offer, enabling her to be tracked whilst preserving her anonymity. The initial endowment distributed to the buyers was put forward to fund tree planting. Each buyer received EUR 15 and was asked to state her bid for a certificate of one ton of carbon offset ( $\leq$ EUR 15). If she won the bid, trees were planted in her name (this was acknowledged by a certificate which was publicly given to the buyer). Each seller was given a certificate of one ton of carbon offset she could either keep, in which case trees were planted in her name, or sell. If she decided to sell the certificate on the offer she stated ( $\leq$ EUR 15), no trees were planted. Subjects ignored that the cost of offsetting one ton of carbon in a five-year period was EUR 15, which enabled to plant 36 trees ${ }^{5}$.

The parameters - recapitulated in the table below - of the experiments are the following: (i) 31 to 37 subjects participated per experiment; (ii) subjects were recruited among volunteering

\footnotetext{
${ }^{4}$ Utility derived from warm-glow (see Andreoni 1990) arises when the act of giving generates utility. It contrasts with the usual case where the individual only cares about the total amount of the carbon offset.

${ }^{5}$ In accordance with the system of reference applied by the non-governmental organization.
} 
students from the École Polytechnique ${ }^{6}$; (iii) the good put up for auctioning was a certificate of one ton of carbon offset; (iv) no information on the market-price of the good was provided; $(v)$ buyers received an initial balance of EUR 15 and sellers a certificate of one ton of carbon offset as an endowment; ( $v i)$ in each trial, even though the seller's market and the buyer's market were independent, bidders and offerers operated simultaneously; (vii) ten trials per experiment were unfolded, one of which was randomly selected as the binding trial; and (viii) BDM, SPA and NPA auction mechanisms were tested.

\begin{tabular}{lccc}
\hline Market environment & BDM & SPA & NPA \\
\hline Auctioned goods & $\mathrm{CO}_{2}$ offset certificate & $\mathrm{CO}_{2}$ offset certificate & $\mathrm{CO}_{2}$ offset certificate \\
Initially endowment & EUR 15 & EUR 15 & EUR 15 \\
Sellers' bound & EUR 15 & EUR 15 & EUR 15 \\
Number of trials & 10 & 10 & 10 \\
Retail price information & Not provided & Not provided & Not provided \\
Optimal responses explained & Suggested & Suggested & Suggested \\
Practice round performed & Pooled & Pooled & Pooled \\
Subject participation & Voluntary & Voluntary & Voluntary \\
Number of subjects & 37 & 34 & 31 \\
\hline
\end{tabular}

Our goal is to question the auction mechanisms' influence on the gap between WTP and WTA, and not to divulge the gap itself, for we consider it as an established fact. Thus, we decided to put an upper-bound on the sellers' choices in order to monitor which of the three market settings best responds to the early disparity. The bounds and endowments definitely create an anchoring effect, but there is no reason that it affects the three incentive-compatible mechanisms differently. Then, we publicly suggested that revealing truthful preferences is a dominant strategy and that they cannot increase their utility following a different strategy. At last, we pooled all performed rounds in the measurement of the gap.

\section{The Becker-DeGroot-Marschak mechanism (BDM)}

\footnotetext{
${ }^{6}$ Multi-cultural elite students in science and engineering, considered in France as highly rational. They are salaried by the French Government. Their curriculum includes courses in economics.
} 
Becker et al. (1964) introduce a mechanism under which buyers (respectively sellers) simultaneously state the highest (respectively lowest) amount they are willing to pay (respectively accept) for the good. In our experiment, each buyer and seller was asked to give, for each of the ten trials, independently and privately, her WTP or WTA by marking an "x" on a recording sheet that listed price intervals, such as in the following illustration. The price intervals ranged from EUR 1-15, in increments of EUR 0.5. After collecting recording sheets from buyers and sellers, the monitor randomly selected one price from the list. If a buyer was willing to pay at least the random price for the certificate of one ton of carbon offset, she bought the item at that price. Otherwise, she did not buy the item. If a seller was willing to accept a price lower than or equal to the random price for the certificate of one ton of carbon offset, she sold the item at that price. Otherwise, she did not sell the item. The random price, all bids and offers, and the number of buyers and sellers willing to buy and sell at the random price were made public after each trial. At the end of the experiment, one of the trials was randomly selected as the binding trial for the take-home pay.

\begin{tabular}{|l|c|c|}
\hline & I will buy (sell) & I will not buy (sell) \\
\hline If the price is EUR 0.0 & -- & -- \\
\hline If the price is EUR 0.5 & -- & -- \\
\hline If the price is EUR 1.0 & -- & -- \\
\hline If the price is EUR 1.5 & -- & -- \\
\hline$\ldots$ & & -- \\
\hline If the price is EUR 14.0 & -- & -- \\
\hline If the price is EUR 14.5 & -- & - \\
\hline If the price is EUR 15.0 & -- & \\
\hline
\end{tabular}

The second-price auction mechanism (SPA)

Buyers were asked to record, for each of the ten trials, privately and independently, the price they were willing to pay for the certificate of one ton of carbon offset. In this case, buyers wrote simultaneously a numerical value on the recording sheet. The monitor collected values and, after each trial, made all bids public, as well as the identification number of the highest bidder and the market-clearing price, the second highest bid. For each trial, sellers wrote simultaneously a selling price the certificate. After each trial, the monitor publicly diffused all offers, the identification number of the lowest offerer and the market-clearing price, the second lowest offer. 
As with BDM, after the tenth trial, the monitor randomly selected one of the trials as the binding trial for the take-home pay for both buyers and sellers.

The random nth-price auction mechanism (NPA)

The random $n$ th-price auction is conducted as follows: $(i)$ for each trial, each bidder submits a bid (resp. an offer) on a recording sheet; ( $i$ ) all bids are ranked from lowest to highest, all offers are ranked from highest to lowest; (iii) the monitor selects a random number $n \in(2, N]$ with $N$ the number of bidders; (iv) the $n-1$ buyers who made the highest bids buy the certificate of one ton of carbon offset at the $n$ th-price and the $n-1$ sellers who made the lowest offers sell the certificate of one ton of carbon offset at the $n$ th-price. The value of $n$, all bids and offers, the buying and selling price, and the number of buyers and sellers willing to buy and sell at the random price, are made public after each trial. Once again, after the tenth trial, the monitor randomly selects one of the trials as the binding trial for the take-home pay for both buyers and sellers.

BDM, SPA and NPA are incentive-compatible. It is not in a buyer's interest to understate her WTP; if the random buying price falls between the stated WTP and the true WTP, the buyer foregoes a beneficial trade. It is neither in a buyer's interest to overstate true WTP; if the random buying price is greater than the true value but less than the stated value, the buyer is required to buy the good at a price greater than her true WTP. The reasoning is identical for the seller. A complementary remark on NPA can be made. Contrary to SPA, subjects, even after having observed that they are not making one of the most attractive bids or offers, perceive that they still have a non negligible probability to win the auction. Because of the randomness of $n$, off-margin bidders can be among the winners in NPA while they would be excluded from the active part of the market in SPA. As well, the endogenously determined market-clearing price (depending on $n$ ) prevents bidders and offerers from using the random market-clearing price as an indicator.

\section{Results and statistical analysis}

Table 1 presents the summary statistics of the experimental results in BDM, SPA and NPA. 
\{Table 1 about here

In all experiments, bidding behavior in the initial trial does not contradict the endowment effect: the mean offer $(\overline{\mathrm{WTA}})^{7}$ is significantly greater than the mean bid $(\overline{\mathrm{WTP}})^{8}$. Still, in BDM, $\overline{\text { WTA }}$ offers decrease and $\overline{\text { WTP }}$ bids increase over time ${ }^{9}$ with experience gained through repetitive auctioning. The $\overline{\mathrm{WTA}} / \overline{\mathrm{WTP}}$ ratios thus decline throughout the ten trials falling from 1.70 in trial 1 to 0.94 in trial 10 (Fig. 1), which corresponds to a $\overline{\text { WTP }}$ increase of $39 \%$ and a $\overline{\text { WTA }}$ decrease of $23 \%$. Concerning variances, we notice that the dispersion around the mean increases for both $\overline{\mathrm{WTP}}(42 \%)$ and $\overline{\mathrm{WTA}}(245 \%)$ from trial 1 to trial 10 . In trials $4-10$, a $t$-test shows that we cannot reject the null hypothesis that $\overline{\mathrm{WTP}}$ and $\overline{\mathrm{WTA}}$ come from the same distribution at the $p<0.05$ level. In BDM, the disparity fades away.

\{Fig. 1 about here\}

In NPA and SPA, the mean selling price exceeds the mean buying price for all ten trials. This also holds for the median bids. We observe similar starting and ending values of the welfare indices. The $\overline{\mathrm{WTA}} / \overline{\mathrm{WTP}}$ ratios remain above one, ranging from 1.35 to 2.71 in NPA, and from 1.28 to 3.07 in SPA (Fig. 1). Bids respectively increase by $69 \%$ and $90 \%$; offers decrease by $13 \%$ in both experiments. The dispersion around WTP follows a different path in NPA and SPA. The dispersion around $\overline{\mathrm{WTA}}$ amplifies in both auction mechanisms from trial 1 to trial 10 (NPA: 103\%; SPA: $86 \%$ ). On the contrary, the dispersion around $\overline{\mathrm{WTP}}$ remains quasi-stationary in SPA $(4 \%)$ but decreases in NPA $(-21 \%)$, which suggests a degree of homogenization between the bids. In all trials, we reject the null hypothesis that $\overline{\mathrm{WTP}}$ and $\overline{\mathrm{WTA}}$ are equal at the 5\% level of a $t$-test. However, we point out that ratios decrease over time approaching the value of one in latter trials. The hypothesis of the equality of the means between SPA and NPA is verified in all

\footnotetext{
${ }^{7}$ The over-bar signifies mean value.

${ }^{8}$ This is also confirmed by the analysis of the medians.

${ }^{9}$ Though they never reach the outside market price, i.e. the upper bound of EUR 15, such as in Bohm et al. (1997).
} 
ten rounds, given the $p$-value. These results are unsurprising in consideration of the likeness of the two auction mechanisms.

Let us now take a closer look at our results and those of the mug experiments from Shogren et al. (2001). At first sight, we obtain contradictory results. In our experiment, the gap disappears in BDM, whereas in theirs, BDM is the only mechanism unable to remove the early gap. Our findings show that repetitions in the BDM mechanism can remove the endowment effect, as long as it steers people's behavior. Likewise, they suggest that the auction mechanism per se can account for the conflicting observations, as we clearly observe different paths of equalization of $\overline{\mathrm{WTP}}$ and $\overline{\mathrm{WTA}}$. We introduce a new tool to study the path of a gap removal: the exponential regression on the $\overline{\mathrm{WTA}} / \overline{\mathrm{WTP}}$ ratios.

\{Fig. 2 about here $\}$

An exponential regression is of a form $y=b e^{a x}$ with $x$ the variable along the $x$-axis, $y$ the regressed values of $\overline{\mathrm{WTA}} / \overline{\mathrm{WTP}}, a$ the amplitude of the decrease (or speed of convergence to equality) and $b$ the $y$-intercept of regression. The function is based on a linear regression, with the $y$-axis logarithmically scaled. $R$-square gives information on the exponential relationship between ratios. We apply this method to the mug experiments (Fig. 2) of Shogren et al. (2001) and to our experiments (Fig. 3).

\{Fig. 3 about here $\}$

The exponential regression is used for two reasons: first, it allows observing phenomena with rapid variations which we observe in both experimental series; second, it allows observing the decreasing ratio up to equality. We try to reveal the mechanism that is the source of a quick decrease, independent of the initial ratio. We can thus consider the fastest decreasing coefficient as the highest speed of convergence to the equality of welfare indices (Table 2).

\{Table 2 about here $\}$ 
Our data from BDM provide an exponentially decreasing relationship between the sequential ratios, whereas the data used by Shogren et al. (2001) do not. Although the $y$-intercept of the regression starts with the same value (both 1.5), the gap disappears in our experiment (illustrated by the speed of convergence -0.04) but stays stationary in the mug experiment (no acceleration to convergence).

We find in both experiments that NPA provides the best exponential relationship between ratios $\left(R^{2}=0.95 ; R^{2}=0.96\right)$ and the highest speed of convergence $(-0.08 ;-0.12)$ toward equality in time. In SPA, the exponential relationship between ratios $\left(R^{2}=0.61 ; R^{2}=0.63\right)$ and the speed of convergence to equality of indices $(-0.06 ;-0.09)$ are significant but lower.

Sudden leaps of increase of the $\overline{\mathrm{WTA}} / \overline{\mathrm{WTP}}$ ratio in SPA - believed to be due to offmargin bidders - explain the differences in $R$-square in comparison with NPA. It is also worthwhile noticing that SPA comes out as the "worst" active market mechanism even though it is frequently used in experiments to reveal agents' preferences. In BDM, our experiment and Shogren et al.'s (2001) experiment both obtain the lowest results in terms of exponential relationship ${ }^{10}$ and speed of convergence toward equality. Therefore, the orderings of convergence in our experiments and those of Shogren et al. (2001) are alike.

\section{Discussion on the differences between mechanisms}

Our experimental results enable us to derive recommendations regarding the choice of the auction mechanism in the context of public good funding. If the initial gap between WTP and WTA is due to the choice of the market mechanism, then the choice of BDM is appropriate, for it produces the smallest initial gap. However, if the auction mechanism is needed to rapidly deflate an excessive initial $\overline{\mathrm{WTA}} / \overline{\mathrm{WTP}}$ gap in a market setting, we suggest the use of NPA.

The differences observed between auction mechanisms require further attention. Let us consider two possible explanations for our results: disappointment aversion and affiliation. In a recent article, Horowitz (2006b) relates that in BDM a bidder may report a higher value than the true one, simply because she is more disappointed from not receiving the good than from

\footnotetext{
${ }^{10}$ The low exponential factor with the BDM is partially explained by the initial smaller difference between WTP and WTA.
} 
receiving it at a higher price, which induces her to increase the chance of winning the auction and to report an overpriced bid. This argument could explain the high WTP observed in BDM. However, it also applies to NPA and SPA, so disappointment aversion cannot explain the difference between BDM and NPA/SPA. Following Milgrom and Weber (1982), we may also consider that common uncertainty about the value of a good creates affiliation between private values, especially in case of unfamiliar goods. However, it is not clear how affiliation could explain the gaps. Besides, the increasing variance of WTP and WTA in time contradicts this interpretation. If values were affiliated and information across rounds was gathered, these variances should decrease.

As a result, we focus on the features of auction mechanisms, particularly those of BDM. As compared to NPA and SPA, two major elements are specific to BDM: (1) individual bids do not affect market-clearing prices, which are determined by an external random process; (2) the bidder's outcome is not affected by others' bids. The mechanism works as if each bidder were bidding against an apparatus which randomly draws a market price. The first element could explain why, even during the early rounds, the difference between WTP and WTA is lower with BDM. Indeed, in this quasi-market mechanism, it appears useless to submit a higher (lower) bid (offer) than the true one. The clearing price being exogenous, subjects can understand that their personal acceptability of prices is what matters most. In some sense, it is easier for a subject to learn how BDM works and to assimilate that submitting her true value is best. With SPA or NPA, it is less straightforward to understand that the price she pays does not depend on her bid; understanding these auction mechanisms is less obvious. Moreover, real-life buyers are used to thinking that lowering the value of a good is profitable ${ }^{11}$. The second element may explain why the convergence process is slower with the BDM mechanism. The outcome being independent from other bidders' or offerers' strategies, subjects have less incentive to pay attention to what others bid or offer and to react to their moves. This induces a slower convergence of indices.

Finally, NPA and SPA are very similar. This similarity could explain the resemblance between behaviors observed in both mechanisms. Yet, in SPA, after the practice rounds, the bidder or offerer can observe whether she is an off-margin bidder or offerer and thus unlikely to win the auction. If that is the case, she has no incentive to fully revise her bids or offers. Given

\footnotetext{
${ }^{11}$ Besides online auctioneers, subjects are more often buyers than sellers in real life. We know that the gap is due to a low WTP the valuation of which is certainly more affected by life habits than the WTA valuation.
} 
the randomness of the number of winning trades in NPA, this argument does not hold, and this surely induces a more rapid convergence of indices. With regard to this difference between SPA and NPA, we should have expected even larger differences in experimental data. Unexpectedly, a high number of subjects did revise their valuations in SPA, even when they were extremely unlikely to be the part of the winning trades.

\section{Public and private motivations in the public good funding}

Some points regarding the specificity of the pure public good also need to be clarified. Let us first focus on this aspect relative to the auction mechanism. In NPA and SPA, the number of traded tons of carbon offset in a period is independent of the bids and offers submitted by the subjects. In any case, in SPA, one ton of carbon offset is bought and sold; in NPA, $n-1$ tons of carbon offset are traded. As a result, in these mechanisms, an extreme form of free-riding is likely to occur, since a subject's bid cannot affect the total public good provision while it affects her payment: buying a certificate has a cost. On the contrary, in the BDM mechanism, subjects' choices can affect the total provision of the public good. Indeed, if a seller chooses a minimum selling price higher than the randomly selected price, she will keep her certificate and one more ton of carbon will be offset. The same reasoning applies for buyers. Put differently, subjects know they can influence the amount of carbon offset in BDM, because their probability of winning the right to buy one certificate is independent of other bidders: the higher the private bid, the higher the chances that a ton of carbon is offset. It is the only auction mechanism in which the level of the public good can be determined by subjects.

This difference between BDM on the one side and NPA and SPA on the other side allows to identify two distinct motivations in the public good funding. First, there is the (selfless) public good motivation to fund the public good, which translates the motivation to buy or keep a certificate for the sake of all. Second, there is the (self-interested) private good motivation of the public good funding, which translates the motivation to buy or keep a certificate because the subject wants to own a certificate and be associated to the offsetting even though it does not modify the number of tons of carbon offset: through the private public good funding, she wants to derive a significant private utility from warm-glow, from social status or guilt alleviation, etc. 
Despite the free-rider incentive, individuals often provide more public goods than traditional economic theory predicts. Public goods are then considered as impure public goods, which are products or services that combine both public and private benefits from the public good. Thus, from the funding perspective, our good becomes an impure public good.

In BDM, both motivations for funding the public good are present, whereas in NPA and SPA, only the private good motivation is existent since subjects cannot affect the total provision of the public good. Now, let us consider $\bar{g}$, the mean value of all bids (WTP) and offers (WTA). After computation over the ten rounds, we observe that $\bar{g}$ is strictly higher with BDM (8.57) than with SPA (7.26) or NPA (7.63). If we take the value of $\bar{g}$ from BDM as a benchmark value of the public good, we can reasonably consider its surplus against SPA and NPA to reveal the value of the public good motivation. The surplus lies in the interval [0.94, 1.31]. The interval indicates that the private good motivation highly exceeds the public good motivation, i.e. subjects are mainly paying for enjoying warm-glow, being identified as contributors of the carbon offsetting or alleviating their feeling of guilt. These results are consistent with the microeconomic analysis, where the private benefit governs the decisions of rational economic agents.

Contrary to the observations where repeat-play public goods games produce declining contributions over time (Andreoni 1988), $\bar{g}$ increases in our experiments. As a matter of fact, if we regress $\bar{g}$ over the number of periods, we obtain a small but strictly positive correlation coefficient (BDM: 0.18; SPA: 0.13; NPA: 0.15). In standard public goods games, the diminution is motivated by free-riding and discouragement of high type players to pursue the provision of the public good alone. We propose two explanations for the increase we observe. First, the funded public good does not only concern the subjects that take part in the experiment but also the population 'outside'. Therefore, the free-riding attitude of some subjects cannot completely alter other subjects' motivations since they do not specifically contribute for these free-riders, whereas they do in regular public goods games. Second, as already mentioned, the private good motivation outperforms the public good motivation, which also explains the absence of the usual decline in subjects' bids ${ }^{12}$. Nevertheless, these findings do not challenge the differences in experimental results observed with Shogren et al. (2001). Even if our experiments gave

\footnotetext{
${ }^{12}$ One could argue that bids increased because of the house money effect. However, Clark (2002) finds no evidence of it in a public good experiment.
} 
prominence to the private good motivation of the public good funding, the good the subjects traded always kept its attribute of a pure public good.

\section{Concluding remarks}

We examined three mechanisms that could rectify the initial gap between WTP and WTA in the trading of a public good. From simple observations of the disparity ratios, we observe different results from Shogren et al. (2001). We can conclude that their findings - which suggest the validity of SPA and NPA in valuing private goods - are either local, or that the public goods are subject to a different bidding behavior.

We think that in a quasi-market setting such as the BDM mechanism, subjects understood the fact that they could decide on the aggregate level of the public good and behaved accordingly. In active markets with endogenous market-clearing prices such as NPA, no subject could influence the level of the public good which acted as a disincentive to augment the level of the public good. Our results show that the disparity between WTP and WTA dropped with repetition in all three mechanisms, suggesting that the economic theory of rationality within markets operates. These results match with those of Brookshire and Coursey (1987) who conclude that the market-like elicitation makes values for the public good more consistent with traditional economic notions. And yet, the theory implies a perfect equality between WTP and WTA, which seems not to be guaranteed when funding a public good ${ }^{13}$.

In addition, more experimental research on private and public values of a public good should be conducted. For example, we could identify more accurately the private good and public good motivations by explicitly insisting on the fact that bids cannot affect the size of the provision of public goods in NPA and SPA. As well, we could conduct experiments where subjects would be purposely deprived from any proof of having financed the public good and where each subject could only observe her final outcome; that way, we could distinguish between the desire to finance the public good and the desire to be identified by others as a generous contributor to the public good.

\footnotetext{
${ }^{13}$ A natural explanation could lie in the lack of direct substitutes to the carbon offset market, that is, the substitution effect.
} 
In terms of public policy, we can ascertain that the main advantage of auction mechanisms when valuing a public good is that they reveal whether subjects derive any public good motivation from the funding. If they do, they submit superior bids and offers with BDM than with NPA. If not, which then suggests equal bids and offers between BDM and NPA, the good does not have a clear public good motivation. In the first case, market settings makes it possible to estimate the optimal level of taxation for the public authority in order to financially support the production of the public good. In the latter case, the public authority is made aware of the undervaluation of the public good's usefulness and the overvaluation of the private utility derived by the subjects. It should then accredit individuals to fund the public good themselves. We actually observe such policy for various public goods associated with a high level of social prestige or recognition, i.e. public goods whose funding contains a high private good component.

\section{Acknowledgments}

We would like to thank Jason Shogren, Bernard Sinclair-Desgagné and Marc Willinger for their helpful comments. Financial support provided by the École Polytechnique-EDF Chair for Sustainable Development and THEMA - Université de Cergy-Pontoise. The usual caveats apply.

\section{References}

Andreoni, J., 1988. Why free-ride? Strategies and Learning in Public Goods Experiments. Journal of Public Economics 37, 291-304.

Andreoni, J., 1990. Impure Altruism and Donations to Public Goods: A Theory of Warm-Glow Giving? Economic Journal 100, 464-477.

Becker, G., DeGroot, M. and Marschak, J., 1964. Measuring Utility by a Single Response Sequential Method. Behavioral Science 9, 226-232.

Bohm, P., Linden, J. and Sonnegard, J., 1997. Eliciting Reservation Prices, Becker-DeGrootMarschak Mechanisms vs. Markets. Economic Journal 107, 1079-1089.

Brookshire, D. and Coursey, D., 1987. Measuring the Value of a Public Good: An Empirical Comparison of Elicitation Procedures. American Economic Review 77, 554-566.

Brouwer, R., Bateman, I., Saunders, C. and Langford, I., 1999. Perception and valuation of risk reduction as a public and private good: Investigating methodological issues in contingent valuation of UV risks in New Zealand. CSERGE Working Paper GEC 99-06.

Cherry, T., Crocker, T. and Shogren, J., 2003. Rationality Spillovers. Journal of Environmental Economics and Management 45, 63-84.

Clark, J., 2002. House Money Effects in Public Good Experiments. Experimental Economics 5, $223-231$

Coase, R., 1960. The Problem of Social Cost. Journal of Law and Economics 3, 1-44. 
Coppinger, V., Smith, V. and Titus, J., 1980. Incentives and Behavior in English, Dutch and Sealed-Bid Auctions. Economic Inquiry 18, 1-22.

Gode, D. and Sunder, S., 1993. Allocative Efficiency of Markets with Zero-Intelligence Traders: Market as a Partial Substitute for Individual Rationality. Journal of Political Economy 101, $119-137$.

Hanemann, W., 1991. Willingness to Pay and Willingness to Accept: How Much Can They Differ? American Economic Review 81, 635-647.

Horowitz, J., 2006a. What Do We Know About the Performance of the Becker-DeGrootMarschak Mechanism. Available at http://faculty.arec.umd.edu/jhorowitz/BDM-Empirics1.doc.

Horowitz, J., 2006b. The Becker-DeGroot-Marschak Mechanism Is Not Necessarily Incentive Compatible, Even for Non-Random Goods. Economics Letters 93, 6-11.

Kahneman, D., Knetsch, J. and Thaler, R., 1990. Experimental Test of the Endowment Effect and the Coase Theorem. Journal of Political Economy 98, 1325-1348.

List, J. and Shogren, J., 1999. Price Information and Bidding Behavior in Repeated Second-Price Auctions. American Journal of Agricultural Economics 81, 942-49.

List, J., 2003a. Does Market Experience Eliminate Market Anomalies? Quarterly Journal of Economics 118, 41-71.

List, J., 2003b. Using random nth-Price Auctions to value Non-Market Goods and Services. Journal of Regulatory Economics 23, 193-205.

Lusk, J. and Rousu, M., 2006. Market Price Endogeneity and Accuracy of Value Elicitation Mechanisms, in List, J. (ed.), Using Experimental Methods in Environmental and Resource Economics, Northhampton, MA: Edward Elgar Publishing.

Lusk, J., Alexander, C. and Rousu, M., 2007. Designing Experimental Auctions For Marketing Research: Effect Of Values, Distributions, And Mechanisms On Incentives For Truthful Bidding. Review of Marketing Science 5, 1-30.

Milgrom, P. and Weber, R., 1982. A theory of auctions and competitive bidding. Econometrica 50, 1089-1122.

Plott, C., 1996. Rational individual behavior in markets and social choice processes: the Discovered Preference Hypothesis, in Arrow, K., Colombatto, E., Perleman, M. and Schmidt, C., (eds.), Rational Foundations of Economic Behavior, Macmillan and St. Martins London.

Plott, C. and Zeiler, K., 2005. The Willingness to Pay/Willingness to Accept Gap, the Endowment Effect, Subject Misconceptions and Experimental Procedures for Eliciting Valuations. American Economic Review 95, 530-545.

Randall, A. and Stoll, J., 1980. Consumer's Surplus in Commodity Space. American Economic Review 71, 449-457.

Sarin, R. and Weber, M., 1993. Effects of Ambiguity in Market Experiments. Management Science 39, 609-615.

Shogren, J., Shin, S., Hayes, D. and Kliebenstein, J., 1994. Resolving Differences in Willingness to Pay and Willingness to Accept. American Economic Review 84, 255-270.

Shogren, J., List, J. and Hayes, D., 2000. Preference Learning in Consecutive Experimental Auctions. American Journal of Agricultural Economics 83, 1016-1021.

Shogren, J., Cho, S., Koo, C., List, J., Park, C., Polo, P. and Wilhelmi, R., 2001. Auction Mechanisms and the Measurement of WTP and WTA. Resource and Energy Economics 23, 97-109.

Smith, V., 1979. An Experimental Comparison of Three Public Good Decision Mechanisms. Scandinavian Journal of Economics 81, 198-215. 
Smith, V., 1991. Rational Choice: The Contrast between Economics and Psychology. Journal of Political Economy 99, 877-897.

Vickrey, W., 1961. Counterspeculation, Auctions, and Competitive Sealed Tenders. Journal of Finance 16, 8-37. 


\section{Appendix}

\section{GENERAL INSTRUCTIONS (translated from French)}

You are about to participate in an experiment about decision making. You are not allowed to speak to your neighbors during the experiment.

All human activities release greenhouse gases, including $\mathrm{CO}_{2}$, that provoke the global warming. This warming endangers the planet, its inhabitants, its ecosystems and biodiversity. One way to fight against global warming is to plant trees. The key elements are the following: the forested surfaces are a carbon trap; young forests store much more carbon than old forests, for trees absorb $\mathrm{CO}_{2}$ as they grow; forests preserve plant and animal biodiversity.

An NGO has launched a project of carbon offsetting by funding the reforestation projects. The purpose is to offset carbon emissions by buying off your own emissions. The compensation is acknowledged by a certificate of one ton of carbon offset.

During your education at the École Polytechnique, you have received and printed, and will certainly do it over in the future, number of documents required for your schoolwork; it is also the case with your consumption of energy (such as light, heating, power supply for computers, etc.) Because you are contributing to the emissions through your consumption of paper and energy via your indirect demand for their manufacturing and distribution, we want to value your willingness to buy off your $\mathrm{CO}_{2}$ emissions.

To this end, we will use a mechanism of purchasing and selling certificates of one ton of $\mathrm{CO}_{2}$ offset, such as the ones we currently hold in our hands.

In couple of weeks, we will get in touch with you by email to inform you about the number of offset tons of $\mathrm{CO}_{2}$ according to your decisions.

We will now conduct an experiment. As you came into the class, some of you were designated as sellers while others were designated as buyers. Indeed, each of you randomly drew a number which decided between buyer and seller. Please keep this number until the end of the experiment: it will serve us to track you on the information cards. In the end of the experiment, during the imbursement, please give us back your numbers.

Only one trial will be binding. We will repeat the experiment ten times. After the tenth trial, the youngest person in the room will randomly draw a number between 1 and 10, which will designate the binding trial.

Please feel free to interrupt us and ask any question you might have in mind.

Without further delay, we are going to read you the instructions concerning the conduct of the experiment. Let's start with those of you who are buyers. 


\section{RANDOM NTH-PRICE AUCTION}

\section{Buyers}

You own $€ 15$. You can now participate in an auction in order to buy a certificate of one ton of $\mathrm{CO}_{2}$ offset. If that is your wish, please submit a bid. The bid you submit can range between $€ 0$ and $€ 15$. If you decide to buy the certificate, trees which are planted on your behalf (acknowledged by your name on the certificate) will compensate one ton of $\mathrm{CO}_{2}$.

\section{To submit a bid, please specify on the information card the price at which you're willing to buy the certificate.}

Rules: your bid is ranked among all bids. We randomly select a number between 2 and $n$ ( $n$ being the total number of offers). In other words, we randomly draw one of the bids and look at its rank. You buy a certificate, at the $n$th price, if your bid is contained in $n-1$ highest bids.

Example: twenty bids are submitted. We randomly draw seven, that is, the seventh-highest bid in the increasing order. You buy a certificate at a displayed price (seventh-highest bid) if your bid is contained in the six highest bids.

Nota bene: the higher your bid, the higher your chances of buying the certificate. If your bid is randomly drawn, your bid becomes the displayed price imposed to the $n-1$ highest bidders. Since you ignore the displayed price ex ante, giving your own value of one ton of $\mathrm{CO}_{2}$ offset enables you to buy the certificate if your value is higher than the displayed price, and prevents you from buying otherwise.

\section{Sellers}

You own a certificate of one ton of $\mathrm{CO}_{2}$ offset. You can now participate in an auction in order to sell your certificate. If that is your wish, please submit an offer. The offer you submit can range between $€ 0$ and $€ 15$. If you decide to sell the certificate with your name on, no ton of $\mathrm{CO}_{2}$ will be offset.

To submit an offer, please specify on the information card the price at which you're willing to sell the certificate.

Rules: your offer is ranked among all offers. We randomly select a number between 2 and $n$ ( $n$ being the total number of offers). In other words, we randomly draw one of the offers and look at its rank. You sell a certificate, at the $n$th price, if your offer is contained in $n-1$ lowest offers.

Example: twenty offers are submitted. We randomly draw six, that is, the sixth-lowest offer in the decreasing order. You sell your certificate at a displayed price (sixth-lowest offer) if your offer is contained in the five lowest offers.

Nota bene: the lower your offer, the higher your chances of selling the certificate. If your offer is randomly drawn, your offer becomes the displayed price imposed on the $n-1$ lowest offers. Since 
you ignore the displayed price ex ante, giving your own value of one ton of $\mathrm{CO}_{2}$ offset enables you to sell the certificate if the price is higher than your value, and prevents you from selling otherwise.

\section{SECOND-PRICE AUCTION}

\section{Buyers}

You own $€ 15$. You can now participate in an auction in order to buy a certificate of one ton of $\mathrm{CO}_{2}$ offset. If that is your wish, please submit a bid. The bid you submit can range between $€ 0$ and $€ 15$. If you decide to buy the certificate, trees which are planted on your behalf (acknowledged by your name on the certificate) will compensate one ton of $\mathrm{CO}_{2}$.

\section{To submit a bid, please specify on the information card the price at which you're willing to} buy the certificate.

Rules: where you've decided to participate in the auction, your offer to purchase is ranked among all offerings purchase. Offerings are classified in ascending order. You take the bid if your offer is highest. However, you only pay for the certificate that the amount of the second offers the highest.

Example: ten bids are submitted. The highest bid is $€ 13$. The second highest bid is $€ 11$. The bidder who proposed $€ 13$ buys the certificate and pays $€ 11$.

Nota bene: the higher your bid, the higher your chances of buying the certificate. Since you ignore the displayed price ex ante, giving your own value of one ton of $\mathrm{CO}_{2}$ offset enables you to buy the certificate if your value is higher than the displayed price, and prevents you from buying otherwise.

\section{Sellers}

You own a certificate of one ton of $\mathrm{CO}_{2}$ offset. You can now participate in an auction in order to sell your certificate. If that is your wish, please submit an offer. The offer you submit can range between $€ 0$ and $€ 15$. If you decide to sell the certificate with your name on, no ton of $\mathrm{CO}_{2}$ will be offset.

To submit an offer, please specify on the information card the price at which you're willing to sell the certificate.

Rules: your offer to sell is ranked among all offers. Offers are ranked in a descending order. You sell a certificate if your offer is the lowest, and you sell it at a displayed price, that is, the secondlowest offer price.

Example: ten offers are submitted. The lowest offer is $€ 5$. The second lowest offer is $€ 7$. The seller who proposes $€ 5$ sells her certificate and earns $€ 7$. 
Nota bene: the lower your offer, the higher your chances of selling the certificate. Since you ignore the displayed price ex ante, giving your own value of one ton of $\mathrm{CO}_{2}$ offset enables you to sell the certificate if the price is higher than your value, and prevents you from selling otherwise.

\section{BDM MECHANISM}

\section{Buyers}

You own $15 €$. You can now participate in an auction in order to buy a certificate of one ton of $\mathrm{CO}_{2}$ offset. If that is your wish, please submit a bid. The bid you submit can range between $€ 0$ and $€ 15$. If you decide to buy the certificate, trees which are planted on your behalf (acknowledged by your name on the certificate) will compensate one ton of $\mathrm{CO}_{2}$.

\section{To submit a bid, please fill in the following table and mark an " $\mathrm{X}$ " for each price at which you're (and are not) willing to buy the certificate.}

Rules: your maximum bid is ranked among all bids. We randomly select one price from the price list, which becomes the displayed price. You buy a certificate if your bid is higher than or equal to the displayed price.

Example: We randomly draw $€ 6$. Since your bid is higher than or equal to $€ 6$, you buy the certificate and pay $€ 6$.

\begin{tabular}{|l|c|c|}
\hline & I will buy & I will not buy \\
\hline If the price is $€ 0$ & $\mathrm{X}$ & \\
\hline If the price is $€ 0.5$ & $\mathrm{X}$ & \\
\hline If the price is $€ 1.0$ & $\mathrm{X}$ & \\
\hline$\ldots$ & $\mathrm{X}$ & \\
\hline If the price is $€ 8.5$ & $\mathrm{X}$ & \\
\hline If the price is $€ 9$ & $\mathrm{X}$ & \\
\hline If the price is $€ 9.5$ & & $\mathrm{X}$ \\
\hline$\ldots$ & & $\mathrm{X}$ \\
\hline If the price is $€ 14.0$ & & $\mathrm{X}$ \\
\hline If the price is $€ 14.5$ & & $\mathrm{X}$ \\
\hline If the price is $€ 15.0$ & & $\mathrm{X}$ \\
\hline
\end{tabular}

Nota bene: the higher your bid, the higher your chances of buying the certificate. Since you ignore the displayed price ex ante, giving your own value of one ton of $\mathrm{CO}_{2}$ offset enables you to buy the certificate if your value is higher than the displayed price, and prevents you from buying otherwise.

\section{Sellers}

You own a certificate of one ton of $\mathrm{CO}_{2}$ offset. You can now participate in an auction in order to sell your certificate. If that is your wish, please submit an offer. The offer you submit can range 
between $€ 0$ and $€ 15$. If you decide to sell the certificate with your name on, no ton of $\mathrm{CO}_{2}$ will be offset.

To submit an offer, please fill in the following table and mark an " $X$ " for each price at which you're (and are not) willing to sell the certificate.

Rules: your minimum offer is ranked among all offers. We randomly select one price from the price list, which becomes the displayed price. You sell a certificate if your offer is lower than or equal to the displayed price.

Example: We randomly draw $€ 10$. Since your offer is lower than or equal to $€ 10$, you sell the certificate and earn $€ 10$.

\begin{tabular}{|l|c|c|}
\hline & I will sell & I will not sell \\
\hline If the price is $€ 15.0$ & $\mathrm{X}$ & \\
\hline If the price is $€ 14.5$ & $\mathrm{X}$ & \\
\hline If the price is $€ 14.0$ & $\mathrm{X}$ & \\
\hline$\ldots$ & $\mathrm{X}$ & \\
\hline If the price is $€ 5.0$ & $\mathrm{X}$ & \\
\hline If the price is $€ 4.5$ & $\mathrm{X}$ & \\
\hline If the price is $€ 4.0$ & & $\mathrm{X}$ \\
\hline$\ldots$ & & $\mathrm{X}$ \\
\hline If the price is $€ 1.0$ & & $\mathrm{X}$ \\
\hline If the price is $€ 0.5$ & & $\mathrm{X}$ \\
\hline If the price is $€ 0.0$ & & $\mathrm{X}$ \\
\hline
\end{tabular}

Nota bene: the lower your offer, the higher your chances of selling the certificate. Since you ignore the displayed price ex ante, giving your own value of one ton of $\mathrm{CO}_{2}$ offset enables you to sell the certificate if the price is higher than your value, and prevents you from selling otherwise. 
Table 1. Summary statistics of the BDM, SPA and NPA mechanisms

\begin{tabular}{|c|c|c|c|c|c|c|c|c|c|c|c|c|}
\hline \multirow[t]{2}{*}{ Auction } & \multirow[t]{2}{*}{ Value measure } & & \multicolumn{10}{|l|}{ Trial } \\
\hline & & & 1 & 2 & 3 & 4 & 5 & 6 & 7 & 8 & 9 & 10 \\
\hline \multirow[t]{8}{*}{ BDM } & WTP & Mean & 6.18 & 7.11 & 7.82 & 8.11 & 8.29 & 8.66 & 8.39 & 8.71 & 8.82 & 8.61 \\
\hline & $\mathrm{N}=19$ & Median & 5.00 & 5.50 & 6.50 & 6.50 & 7.00 & 7.00 & 7.00 & 7.50 & 7.50 & 7.50 \\
\hline & & Variance & 12.51 & 15.52 & 15.39 & 15.43 & 15.09 & 15.86 & 15.27 & 14.62 & 14.37 & 17.74 \\
\hline & WTA & Mean & 10.53 & 9.47 & 9.56 & 8.42 & 8.92 & 8.69 & 9.53 & 9.19 & 8.67 & 8.06 \\
\hline & $\mathrm{N}=18$ & Median & 10.00 & 10.00 & 10.00 & 8.75 & 9.50 & 9.75 & 10.00 & 10.00 & 9.75 & 8.25 \\
\hline & & Variance & 6.07 & 12.34 & 18.03 & 18.60 & 20.95 & 21.53 & 19.75 & 16.86 & 17.79 & 20.97 \\
\hline & Ratio of mean WTA/WTP & & 1.70 & 1.33 & 1.22 & 1.04 & 1.08 & 1.00 & 1.13 & 1.06 & 0.98 & 0.94 \\
\hline & $t$-test of means $\mathrm{s}^{\mathrm{a}}$ & & -3.85 & -1.46 & -0.83 & 0.27 & 0.06 & 0.46 & -0.39 & 0.09 & 0.58 & 0.91 \\
\hline \multirow[t]{8}{*}{ SPA } & WTP & Mean & 3.47 & 3.91 & 4.69 & 5.43 & 5.68 & 5.71 & 6.01 & 6.50 & 5.46 & 6.59 \\
\hline & $\mathrm{N}=17$ & Median & 3.00 & 4.10 & 5.00 & 5.60 & 5.80 & 6.05 & 7.00 & 7.00 & 7.00 & 7.00 \\
\hline & & Variance & 9.64 & 6.68 & 5.52 & 5.42 & 6.15 & 7.71 & 8.86 & 14.50 & 12.56 & 10.04 \\
\hline & WTA & Mean & 10.66 & 8.74 & 8.47 & 9.07 & 8.59 & 9.82 & 9.40 & 8.32 & 9.52 & 9.23 \\
\hline & $\mathrm{N}=17$ & Median & 10.00 & 9.00 & 8.00 & 9.00 & 7.00 & 10.00 & 8.00 & 8.00 & 8.00 & 8.00 \\
\hline & & Variance & 16.60 & 19.56 & 14.03 & 22.27 & 20.72 & 29.45 & 29.44 & 32.86 & 26.44 & 30.86 \\
\hline & Ratio of mean WTA/WTP & & 3.07 & 2.23 & 1.81 & 1.67 & 1.51 & 1.72 & 1.57 & 1.28 & 1.75 & 1.40 \\
\hline & $t$-test of means $\mathrm{s}^{\mathrm{a}}$ & & -5.28 & -3.41 & -3.06 & -2.35 & -1.78 & -2.30 & -1.78 & -0.59 & -2.21 & -1.20 \\
\hline \multirow[t]{8}{*}{ NPA } & WTP & Mean & 3.97 & 3.98 & 4.77 & 4.93 & 4.77 & 5.19 & 6.18 & 6.12 & 6.85 & 6.72 \\
\hline & $\mathrm{N}=15$ & Median & 2.50 & 4.00 & 5.00 & 5.12 & 5.14 & 5.01 & 7.00 & 6.50 & 7.00 & 7.26 \\
\hline & & Variance & 12.67 & 6.92 & 4.83 & 4.30 & 5.40 & 6.33 & 5.81 & 6.54 & 7.77 & 10.03 \\
\hline & WTA & Mean & 10.75 & 10.52 & 10.29 & 10.22 & 9.86 & 9.05 & 9.17 & 9.14 & 9.23 & 9.37 \\
\hline & $\mathrm{N}=16$ & Median & 10.50 & 10.00 & 9.74 & 9.65 & 8.77 & 8.50 & 8.49 & 8.35 & 8.09 & 8.50 \\
\hline & & Variance & 10.19 & 6.99 & 6.32 & 9.46 & 10.31 & 13.75 & 16.67 & 13.30 & 14.08 & 20.64 \\
\hline & Ratio of mean WTA/WTP & & 2.71 & 2.64 & 2.16 & 2.07 & 2.07 & 1.74 & 1.48 & 1.49 & 1.35 & 1.39 \\
\hline & $t$-test of means $\mathrm{s}^{\mathrm{a}}$ & & -5.06 & -6.45 & -6.21 & -5.17 & -4.60 & -2.87 & -1.90 & -2.10 & -1.40 & -1.33 \\
\hline
\end{tabular}

$\mathrm{H}_{0}$ : Mean WTP - Mean WTA $=0 ; \mathrm{H}_{1}$ : Mean WTP - Mean WTA $<0$

${ }^{\mathrm{a}} t$-test: reject $\mathrm{H}_{0}$ at the $5 \%$ level 
Table 2. Exponential regression statistics

\begin{tabular}{llrr}
\hline Auction & Regression statistics & Our experiments & $\begin{array}{r}\text { Mug experiments } \\
\text { by Shogren } \text { et al. }\end{array}$ \\
\hline \multirow{2}{*}{ BDM } & Speed of convergence $(a)$ & -0.04 & -0.00 \\
& $y$-intercept of regression $(b)$ & 1.5 & 1.5 \\
& $R$-square & 0.69 & 0.00 \\
\hline \multirow{2}{*}{ SPA } & Speed of convergence $(a)$ & -0.06 & -0.09 \\
& $y$-intercept of regression $(b)$ & 2.5 & 1.9 \\
& $R$-square & 0.61 & 0.63 \\
\hline NPA & Speed of convergence $(a)$ & -0.08 & -0.12 \\
& $y$-intercept of regression $(b)$ & 2.9 & 2.8 \\
& $R$-square & 0.95 & 0.96 \\
\hline
\end{tabular}




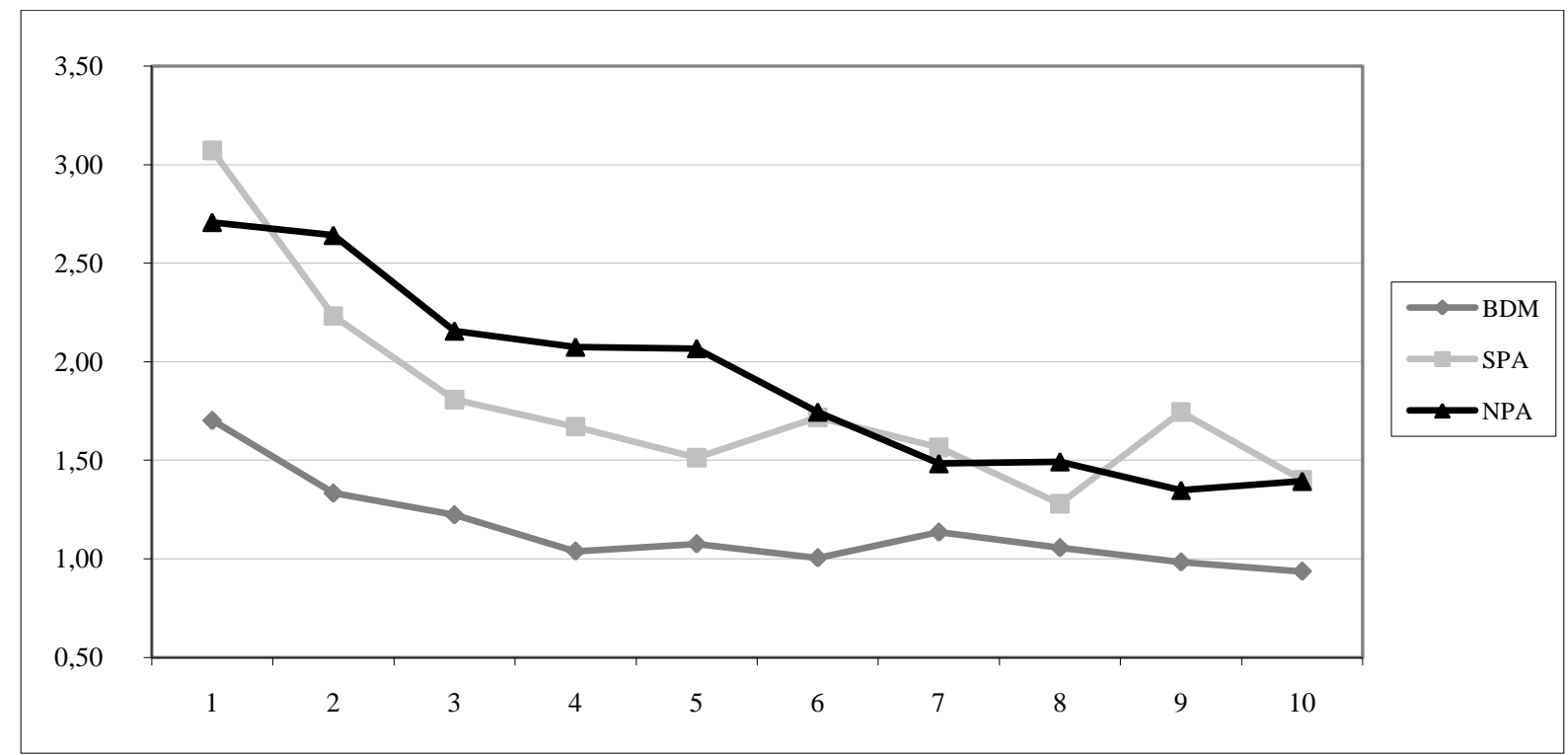

Fig. 1. $\overline{\mathrm{WTA}} / \overline{\mathrm{WTP}}$ disparity from trial 1 to trial 10 


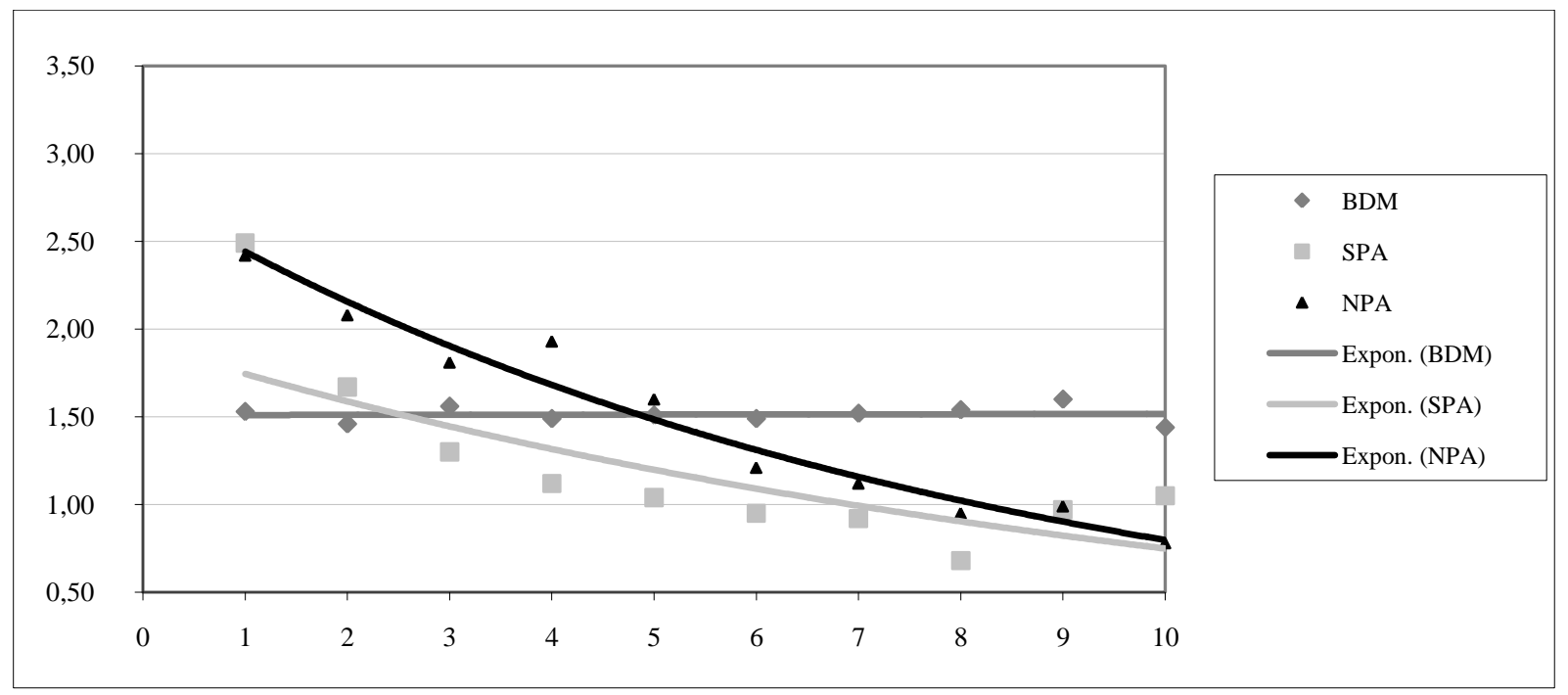

Fig. 2. Exponential regression of WTA/WTP disparity

from mug experiments by Shogren et al. (2001) 


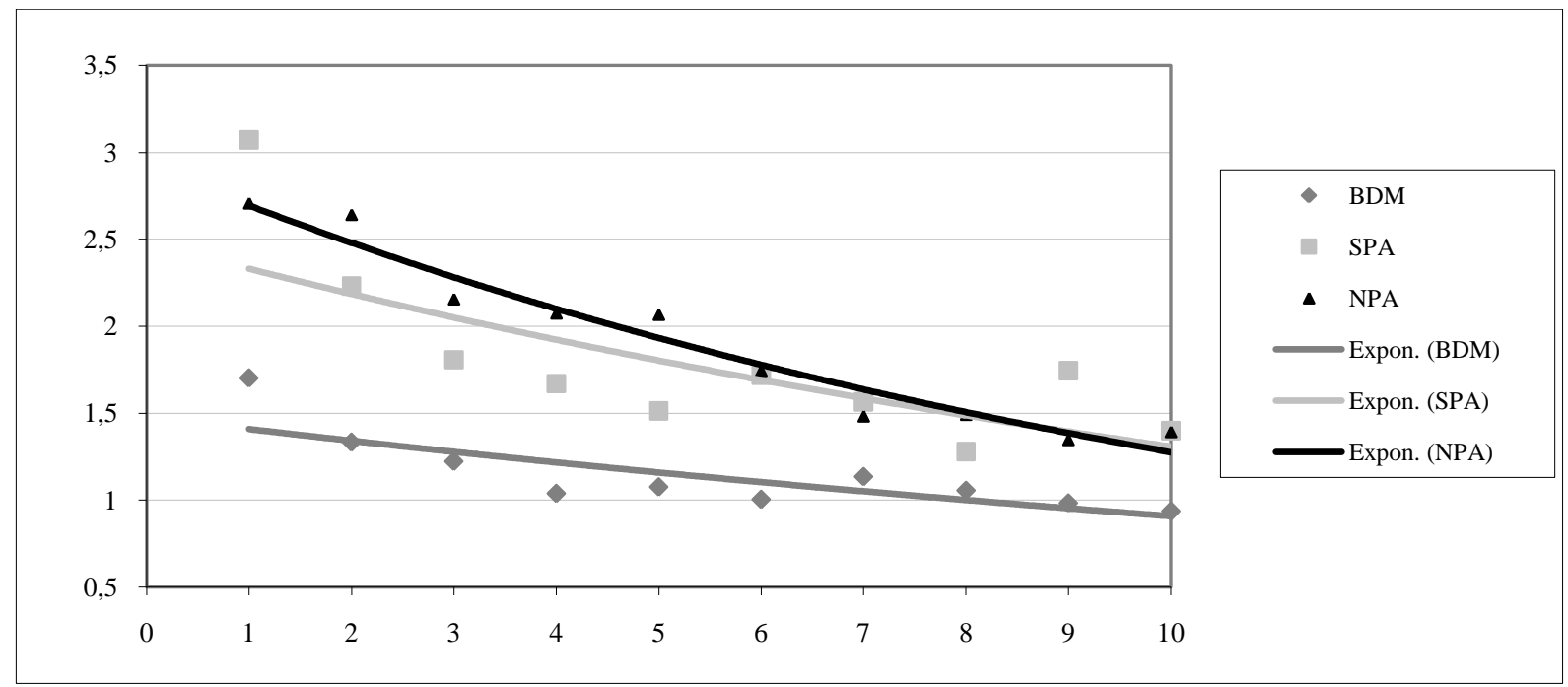

Fig. 3. Exponential regression of $\overline{\mathrm{WTA}} / \overline{\mathrm{WTP}}$ disparity 